Purpose: the research is to examine causes and results of borrowing from the Bantu languages into the lexicon of South African English.

Results: the findings suggest that the South African English lexicon is a friendly-to-borrow system which is adjustable for the needs of interethnic communication and integration of cultures in contact. The Bantu languages provide a productive source of direct and indirect loans including lexical, morphological, structural, and semantic borrowings. There can be a correlation between the etymological sources of borrowing and semantic fields the loans appeal to. It supports the idea about the nonisomorphic categorization of referents in languages. The Bantu loans in South African English are well assimilated units that function to meet speakers' naming, expressive and pragmatic intentions. The Bantu loans appear in two groups: some function as common to all the varieties of South African English while others are specific to a particular variety spoken as the first or the second language.

Discussion: The English-Bantu contacts are encouraging the formation of a polyethnic identity in the South African republic.

Keywords: South African English, varieties of English, borrowing, Bantu languages, assimilation, multicultural

Vitae

Olena Avramenko is a $\mathrm{PhD}$ student of the Department of English Philology, Zaporizhzhia National University. Her areas of research interests include sociolinguistics, language change and variation, multilingualism, intercultural communication, varieties of English, language contacts.

Correspondence: av30el@gmail.com

Надійшла до редакції 25 березня 2021 року Рекомендована до друку 8 квітня 2021 року

Олена Левченко

ORCID: orcid.org/000-0002-7395-3772

Наталія Лотоцька

ORCID: orcid.org/0000-0001-6692-196X

DOI 10.31558/1815-3070.2021.41.13

УДК 821.161.2”1960-2016”-3.09Іваничук Р.:81'42

\title{
КОЛЬОРОНАЗВА БІЛИЙ ЯК МАРКЕР ІДІОЛЕКТУ (НА МАТЕРІАЛІ ТЕКСТІВ Р. ІВАНИЧУКА)
}

Статтю присвячено кольороназвам як важливим складникам моделювання навколишнього світу мовною особистістю. Кольороназва білий формує ядро кольорів у лінгвістичних студіях $і$ є найчастотнішою номінацією кольору в дослідницькому корпусі Р. Іваничука (ДКРІ). Застосовано корпуснобазовану та лінгвокогнітивну методики для опису й аналізу кольороназви білий як маркера ідіолекту. У процесі дослідження виявлено структурно-семантичні моделі словосполук зі словом білий, виокремлено тематичні групи досліджуваної кольороназви, високочастотні колокації з досліджуваною кольороназвою, простежено семантику та символіку цьього кольору та визначено прототип білого в ідіолекті Р. Іваничука. Здобуті кількісні дані порівняно з кількісними показниками дослідницького корпусу художньої прози 1960-2016 рр. (ДКХП) для виокремлення індивідуально-авторських сполук.

Ключові слова: ідіолект, кольороназва, корпус текстів, колокат, колокачія, порівняльна конструкція, прототип, статистика, сполучуваність. 
Постановка наукової проблеми та її актуальність. Кольороназви є важливими елементами для конструювання мовної картини світу певної лінгвокультурної спільноти (Семашко 2008). Своєрідність вживання кольороназв, що беруть участь у моделюванні реального світу в художніх творах, стає проявом індивідуального авторського письма, авторського бачення навколишнього світу.

Кожна творча особистість, зокрема письменник, по-своєму відображає навколишній світ, добирає та використовує мовні засоби. Постать Романа Іваничука знакова для української літератури др. пол. XX ст. - поч. XXI ст. У лінгвістичній науці вивчення індивідуального мовлення письменника переважно здійснюють на матеріалі його художніх текстів.

Сьогодні активізовано застосовують низку підходів до дослідження художніх текстів, зокрема корпуснобазований та лінгвокогнітивний. Корпуснобазовані дослідження розкривають непередбачувані моделі сполучуваності на базі корпусу текстів, когнітивний підхід уможливлює обгрунтування авторського відбору мовних засобів (Єсипенко 2007: 8). Так, корпус текстів конкретного автора дає змогу вивчати мовлення письменника на різних мовних рівнях та представити частотність мовних одиниць, їхню сполучуваність. В українській лінгвістиці мало дослідженою залишається проблема аналізу колокацій у художніх текстах, які дають важливу інформацію про специфіку авторського ідіолекту. В. Левицький зазначає, що між якісними та кількісними особливостями мовної структури тексту існує внутрішня взаємозалежність, що зумовлює підпорядкованість частоти мовних одиниць у мовленні певним статистичним закономірностям, i, своєю чергою, дає змогу отримати об'єктивні дані, незалежні від суб’єктивного сприйняття дослідника (Левицкий 2007: 5).

Відсутність грунтовних досліджень ідіолекту Романа Іваничука та застосування сучасних підходів аналізу на базі створеного корпусу текстів, визначає актуальність цього дослідження.

Аналіз останніх досліджень. Кольороназви в українській мові досліджували І. Бабій, О. Бистрова, Л. Гливінська, В. Горобець, Г. Губарева, О. Дроботун, О. Клєщова, Т. Ковальова, Н. Кухар, Л. Макаренко, В. Півень, І. Підгородецька, Г. Савчук, Т. Семашко, Н. Сологуб, Л. Супрун, Л. Шулінова, С. Шуляк тощо. Аналізові кольороназв у художніх прозових текстах присвячено розвідки О. Клєщової, З. Годунок, І. Бабій, О. Дроботун. Так, І. Бабій вивчає семантику, структуру та стилістичні функції назв кольорів у сучасній українській мові на матеріалі текстів В. Стефаника, М. Коцюбинського, М. Хвильового (Бабій 1997). Г. Губарева системно описує кольороназви, беручи до уваги кількісне наповнення домінантних колірних номінацій (Губарева 2002). В. Півень вивчає ідіостиль С. Городинського за сюжетно-тематичним спрямуванням барвопозначення (Півень 2007). Л. Супрун здійснює семантикостилістичний аналіз значень назв кольорів для виявлення особливостей їх використання у творах українських письменників О. Гончара, М. Стельмаха, П. Загребельного, визначає лексикосемантичні поля кольороназв, описує й аналізує частотність використання лексем на позначення кольору в художньому мовленні кожного автора (Супрун 2009).

Основні методологічні принципи лінгвістичного аналізу індивідуального мовлення майстрів художнього слова сформували у своїх працях такі відомі українські лінгвісти, як К. Голобородько， Л. Дударенко， В. Жайворонок， О. Костецька， Л. Кочан， Л. Пустовіт, О. Селіванова, Н. Сологуб, Л. Ставицька, та ін.

Одним із важливих аспектів аналізу ідіолекту є дослідження сполучуваності одиниць у текстах автора. На думку В. Захарова, «корпуси й інструментарій корпусної лінгвістики дають змогу виявити й суттєво розширити лексичний фонд стійких словосполук різного типу й особливості їх використання» (Захаров 2015).

Аналіз сталих сполук різних типів у межах ідіолекту привертає дослідників. В. Наумов зазначає, що потенціал мовної особистості реалізовувати сукупність мовних засобів «здебільшого вербалізується за допомогою стійких мовних зразків - ментального лексикону» (Наумов 2006: 12). В. Наумов додає, що «мовні (мовленнєві) навички є несвідомими марке- 
рами (індикаторами) особистості або певної частини мовного колективу, об'єднаного спільними (соціальними, віковими, статевими) ознаками (Наумов 2006).

До представників української школи статистичної лінгвістики можна віднести М. Білинського, С. Бук, Н. Дарчук, В. Левицького, В. Перебийніс, В. Теслюка, В. Широкова. Для багатоаспектного дослідження ідіолектів лінгвісти вдаються до кількісного опису доробку письменників, що дає точну інформацію про особливості функціонування лексики в їхній творчості (Бук 2012: 86).

Мета цієї розвідки - описати та проаналізувати специфіку вживання кольороназви білий у дослідницькому корпусі Романа Іваничука (ДКРІ). Завданнями $є$ представити структурно-семантичні моделі словосполук зі словом білий, виокремити тематичні групи досліджуваної кольороназви, виявити високочастотні колокації з компонентом білий, проаналізувати семантику та символіку кольору та визначити його прототипні референти в ідіолекті Р. Іваничука.

Матеріалом дослідження послугували тексти українського письменника Р. Іваничука. Для проведення дослідження було створено корпус текстів Р. Іваничука, до якого увійшли 16 історичних романів і одна історична трилогія (1962-2016 рр.), як-от: «Край битого шляху», «Мальви», «Журавлиний крик», «Черлене вино», «Вода 3 каменю», «Шрами на скалі», «Бо війна війною», «Орда», «Євангеліє від Томи», «Манускрипт з вулиці Руської», «Через перевал», «Вогненні стовпи», «Саксаул у пісках», «Хресна проща», «Четвертий вимір», «Голоси знад вод Генісарета», «Я ще не писав про Донбас». Обсяг корпусу становить понад 1,295 млн слововживань (ГРАК: http://uacorpus.org/).

Належить додати, що для порівняння статистичних показників та «якісних» даних було укладено дослідницький корпус художньої прози 1960-2016 рр. (ДКХП) на базі корпусу ГРАК, що, своєю чергою, уможливлює виокремлення лексичних маркерів авторського ідіолекту. Його створено з урахуванням часового критерію: до уваги було взято тексти представників художньої прози, написаних в період 1960-2016 рр.

Предметом дослідження є особливості вживання кольороназви білий в ідіолекті Романа Іваничука, тим часом об'єктом дослідження виступають лексико-семантичні та статистичні особливості вживання кольоронави БІЛИЙ: типові моделі сполучуваності, високо- та низькочастотні колокати кольору білий, семантика кольороназви та прототипні референти досліджуваного кольору.

Новизна дослідження полягає в тому, що вперше об'єктом аналізу стали кольороназви в художніх текстах Р. Іваничука за допомогою корпуснобазованих, лінгвокогнітивних, статистичних підходів.

Теоретичне цінність праці полягає в тому, що вона поглиблює теоретичні засади вивчення ідіолекту письменника. Отримані результати дослідження сприяють розширенню знань в сфері аналізу художнього тексту.

Виклад основного матеріалу дослідження. Аналіз сталих сполук різних типів у межах ідіолекту тривалий час привертають увагу дослідників. Так, Н. Бойко стверджує, що «художній твір письменника $є$ моделлю двох складників — ідіосвіту (явищ дійсності, осмислених, оцінених і відтворених інтелектом автора) й ідіолекту (системи мовних знаків, насамперед лексико-семантичного та фразеологічного рівнів» (Бойко 2017: 39); «ідіолект одночасно представляє внутрішній аспект психічної діяльності людини, іiі ментальність, специфіку свідомості, сукупність уявлень про світ усередині конкретної традиції і свідчить про внесок письменника в літературну мову, розмаїття експресивних засобів мови художньої літератури, способи, прийоми й шляхи вербалізації естетичної функції мови, аспекти її декодування в конкретному тексті» (Бойко 2017: 43).

На підставі спостереження корпусних даних щодо невідповідності меж значень і лексичних одиниць було розроблено «корпусну модель значення» (Tognini-Bonelli 2000: 214), суть якої полягає в тому, що значення не зосереджується в межах однієї лексичної одиниці, а розповсюджується на послідовність слів у словосполуці - колокації. При цьому, за 
Дж. Синклером, моделлю вважають сполуку слів, що двічі трапилася в тексті (Sinclair 1991: 57). У такий спосіб завдяки працям Дж. Синклера в галузі корпусної лінгвістики було відкрито шлях до нового розуміння словосполуки загалом (Marcinkevičienė 2010: 44) i сформульовано теоретичні засади корпусного підходу (Sinclair 1991; Дарчук 2013; Бобкова 2014; Ситар 2018).

Кількісне представлення якісних явищ полягає у приписуванні досліджуваним лінгвістичним явищам, які мають якісну природу, квантитативної оцінки, унаслідок чого ці явища можна досліджувати як кількісні об’єкти (Тулдава 1987: 32-33). Частотність лексичної одиниці - це важлива характеристика слова, оскільки вона свідчить про активність його функціонування в тексті, про його вагу у статистичній структурі тексту тощо.

Номінації кольору в авторському тексті дають інформацію про кольорову картину світу письменника та демонструють авторське бачення, культурний досвід. Свого часу А. Вежбицька досліджувала кольороназви за допомогою стійких асоціативних зв'язків між концептом кольору та його прототипом (Вежбицкая 1996: 231-290). Різноаспектні лінгвістичні дослідження свідчать, що в лексиконі носіїв кожної мови є певне ядро кольорів: білий, чорний та червоний. Так, О. Василевич (Василевич 2005) розглядає слова на позначення білого, чорного, червоного кольорів такими, що виникли першими, а В. Тернер (Тернер 1983) виявив надання переваги цим кольорам у символіці первісних ритуалів. Статистичні дослідження В. Московича (Москович 1960) підтверджують, що чорний, білий, червоний кольори переважають у більшості мов. Семантичні дослідження С. Кацнельсона (Кацнельсон 1965) доводять, що головними ахроматичними кольорами є білий та чорний, а серед хроматичних - червоний.

Білий є високочастотною кольороназвою у ДКРІ. Серед високочастотних сполук із кольороназвою білий у ДКРІ виявлено такі моделі: 3 прийменником у препозиції - на |білий| 70/54,051, у |білий| 47/36,29, в |білий| 42/32,43, з |білий| 33/25,48, серед |білий| 15/11,58, по |білий| 14/10,81, до |білий| 14/10,81, під |білий| 6/4,63, з сурядним сполучником й - й |білий| $18 / 13,9, \mid$ білий $\mid \check{u} 3 / 2,32$. Тим часом у ДКХП представлено: моделі з прийменником - на |білий| 31,23, у |білий| 30,94, в |білий 28,31 , з |білий| 24,67, серед |білий $\mid$ 7,94, до |білий 7,32 , по |білий| 5,62 , моделі з сполучником - $i \mid$ білий $\mid$ 13,6, |білий $\mid$ i 6,96, й |білий| 5,23, та |білий 4,3 , |білий $\mid$ й 3,74 . Отримані дані подано на діаграмі 1 (до уваги взято частотність $\geq 2$ ).

Діаграма 1

\section{Високочастотні сполуки з компонентом білий}

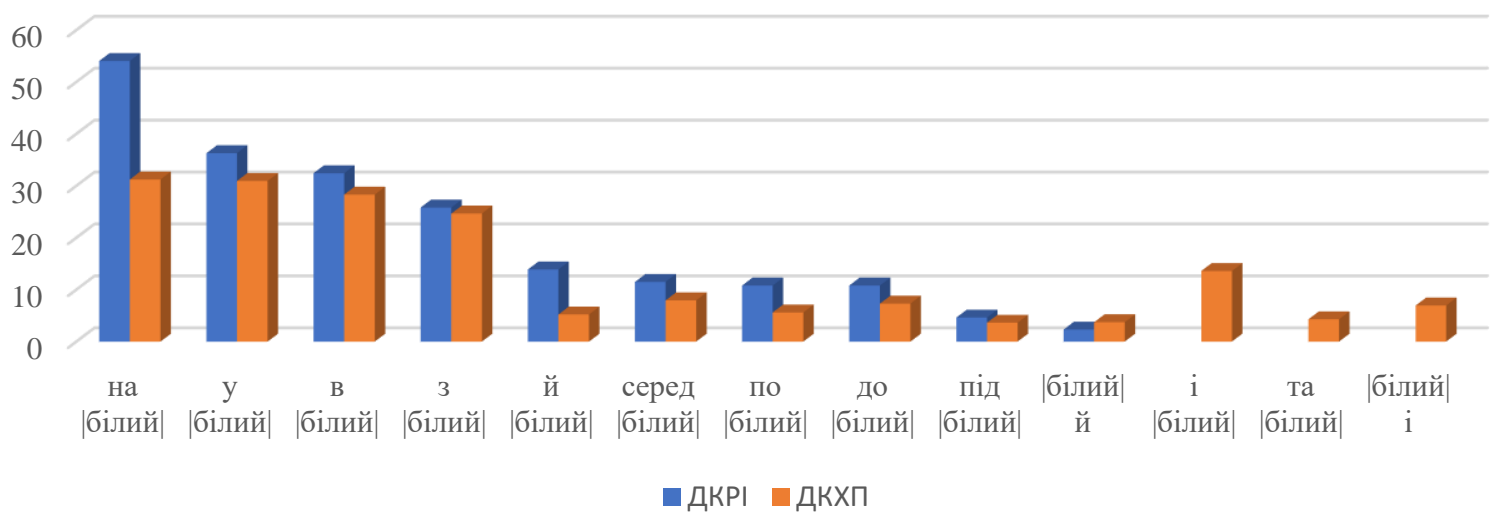

Із порівняння даних дослідницьких корпусів випливає, що високочастотними сполуками є на |білий|, y | білий|, в | білий|, з | білий |. Отримані показники корелюють у ДКРІ і ДКХП,

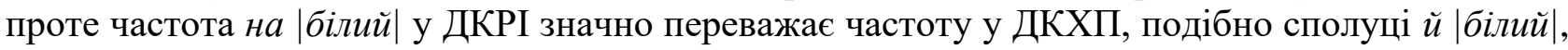
ці чинники вирізняють мовлення Р. Іваничука.

\footnotetext{
${ }^{1}$ Абсолютна частота вживання/відносна частота вживання для ДКРІ
} 
У текстах Р. Іваничука наявні структурні моделі сполук, яким властива семантика інтенсивності (розпечений до білого $3 / 2,32$, запити до білої гарячки $1 / 0,77$ ), фразеологічні сполуки (серед білого дня 15/11,58, на білому світі 13/10).

У ДКРІ білий переважно виступає атрибутом іменників (колокатів) у конструкції Adj + N. Колірні атрибути застосовано до іменників, належних до таких тематичних груп ${ }^{2}$, здобуті дані представлено на діаграмі 2:

ВСЕСВІТ. ПРОСТІР. ЧАС. ЗЕМЛЯ: НЕЖИВА ПРИРОДА. Простір та його елементи. Природні стихії та явища: світ 17/13,12, гора 12/9,26, камінь 6/4,63, пляма 5/3,86, смуга 4/3,09, прогалина, частокіл 3/2,32, дорога, море, острівецьь, скеля, смужкка, туман, пороша 2/1,54; видма, кружало, напис, небо, оболок, острів, пасмуга, тракт, хмаринка, хмарка, вершина гір, поле, тло, віхола, іскринка, імла, мево, мрево, полум'я, пал, повінь, потоп, сніг, сяйво, тінь 1/0,77. Будівля, споруда, приміщення та їхні частини: стіна, хата 6/4,63; вітрильник, намет, підвіконня, обрус 2/1,54; вежа, вікно, гонт, касарня, колона, стеля, теплохід, храм 1/0,77. Матеріал, речовина, частина чогось: рінь 4/3,09; габа, простирадло 3/2,32; запона, мармур, піна, полотно, покривало, серпанок, сукно 2/1,54; брила, верета, дим, димок, корал, крупинка, манна, місиво, мука, нафта, попіл, пісочок, постіль, простирадло, скатертина, стяг, фарба, фільи, штора 1/0,77. Предмет: хрест 7/5,41; прапор 4/3,09; бохонець, книга, стріла, обруч, скіпок, гребінещь, перука, тріска 1/0,77. Форма, фізичні характеристики: квадрат 2/1,54; масть, трикутничок (комірець) 1/0,77. Надприродні явища: магія, мара, чудо 1/0,77. Час, часовий відрізок, часові характеристики: день 15/1 1,58, зима 7/5,41; ранок, днина 1/0,77. Населений пункт та адміністративні одиниці: Біла Гора 12/9,25, Біле море 7/5,41, Біла Церква 4/3,09; Біла Лебедиия, Білий Камінь, Біла Кобила 3/2,32; Біле місто, Атени, Білий Слон 1/0,77.

ЗЕМЛЯ: ЖИВА ПРИРОДА. ЛЮДИНА ЯК ЧАСТИНА ЖИВОЇ ПРИРОДИ. Тварини: кінь 16/12,35, ведмідь, лебедиия 3/2,32, огир 2/1,54; віл, кобила, лебедь, лев, орел, пес, слон, чайка 1/0,77. Рослини: ряст, ивіт 5/3,86, береза 3/2,32; чаша лотоса, лілія, троянда 2/1,54; квасолина, квітка, китиці, лілея, півонія, стокротка $1 / 0,77$. Людина та родинні зв'язки: пані 17/5,41, молодець 6/4,63, дівчина 5/3,86; віла 3/2,32; чар, люди, дівчинка, конфедератка 2/1,54; зараза, челядь, ворог, громада, євнух, жінка, король 1/0,77. Тіло людини, частини тіла: зуб 9/6,95; голівка, постать 4/3,09; груди, душа, ребро, шия 3/2,32; око, тіло 2/1,54; кістяк, нога, цичі, перса 1/0,77. Одяг: сорочка 10/7,72, кожушок 7/5,41; рукавички, чалма 6/4,63; намітка, комірець 5/3,86; фередже, хустина 4/3,09; пройма, бараниия, плахта, одежа, кожух, льоля, рантух, пелерина, блузочка 3/2,32; штани, туніка, мундир, кирея, балахон 2/1,54; манжет, черкеска, вбрання, гудзик, бурнус, кучма, кокарда, кошуля, плащ, фартушок, папаха, свита, тюрбан, фата, холошні 1/0,77. Продукти: хліб 4/3,09. Стан: голизна, смага, тиша 1/0,77. Емоції: втіха 1/0,77. Хвороби: зараза 1/0,77.

Тематичні групи колокатів кольороназви білий у ДКРІ

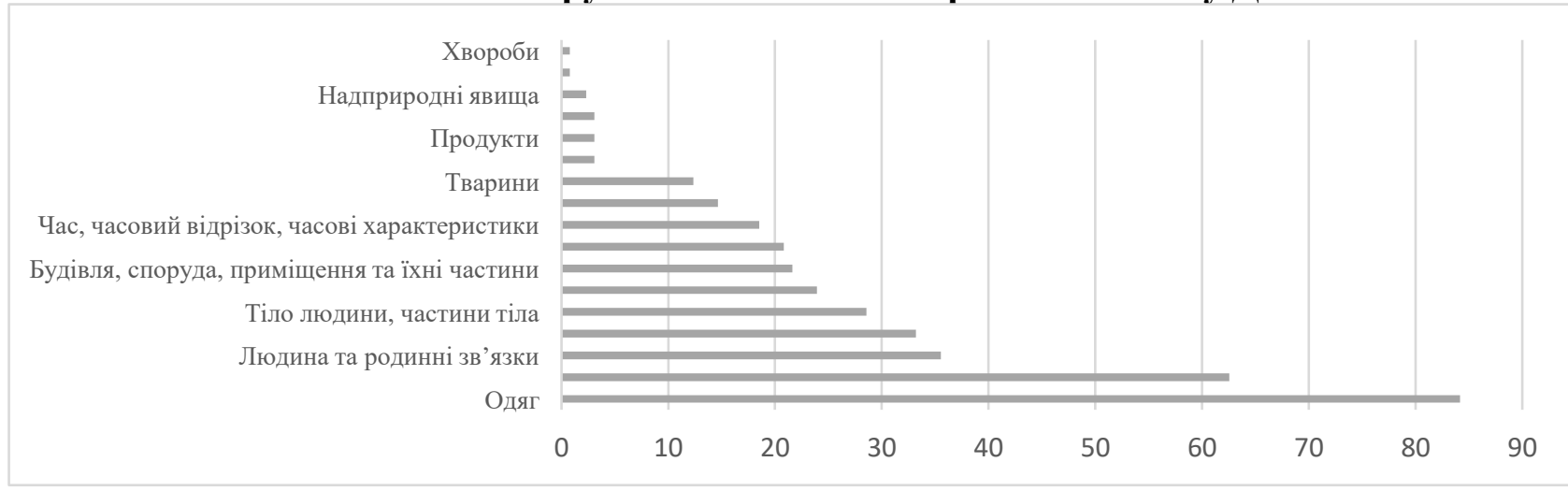

2 Модифіковано класифікації М. Мухіна (Мухин 2011), Н. Сніжко (Сніжко 2016). 
Проведене дослідження дає змогу стверджувати, що кольороназва білий виступає найчастіше атрибутом одягу (23\%), простору, природніх явищ та стихій (17\%). У ДКРІ 3 кольороназвою білий ужито назви населених пунктів та адміністративних одиниць: Біла Гора, Біла Церква; Біла Лебедиия, Білий Камінь, Біла Кобила; Біле місто, Білі Атени, Білий Слон, Біле Море.

Складниками колокацій з кольороназвою білий у Р. Іваничука є діалектизми, архаїзми, рідковживані слова: чалма, намітка, пройма, бараниця, плахта, рантух, пелерина, кирея, черкеска, бурнус, кучма, кокарда, папаха, тюрбан, частокіл, гонт, видма, оболок, віла, смага, цииі, перса, пороша, мево, мрево, огир, габа, фільи, бохонеиь. У ДКРІ виявлено низку індивідуально-авторських словосполук з кольороназвою білий, як-от: біла голизна, біла втіха, біла зараза, білий пал, білий гамівник, біла павутиия, біла бараниця, біла видма, білий фільи, білий тонт, білий молодець, біла ичия, біла пройма, біле ряботиння, біле мево, біла касарня, пломеніти білим полум'ям.

У ДКХП наявні такі високочастотні колокати атрибута білий (до уваги взято 20 найчастотніших колокатів): світ 14,94, сорочка 11,12, день 10,55, халат 10,17, кінь 5,02, церква 4,4, зуб 4,18, стіна 3,83, пляма 3,28, сніг 3,08, рука 2,44, хмара 2,27, простирадло 2,25, гарячка 2,11, колір 1,95, хліб 1,92, nanip 1,89, людина 1,77, тіло 1,17. На діаграмі 3 подано високочастотні колокати кольороназви білий у ДКРІ і ДКХП.

Діаграма 3

Колокати кольороназви білий

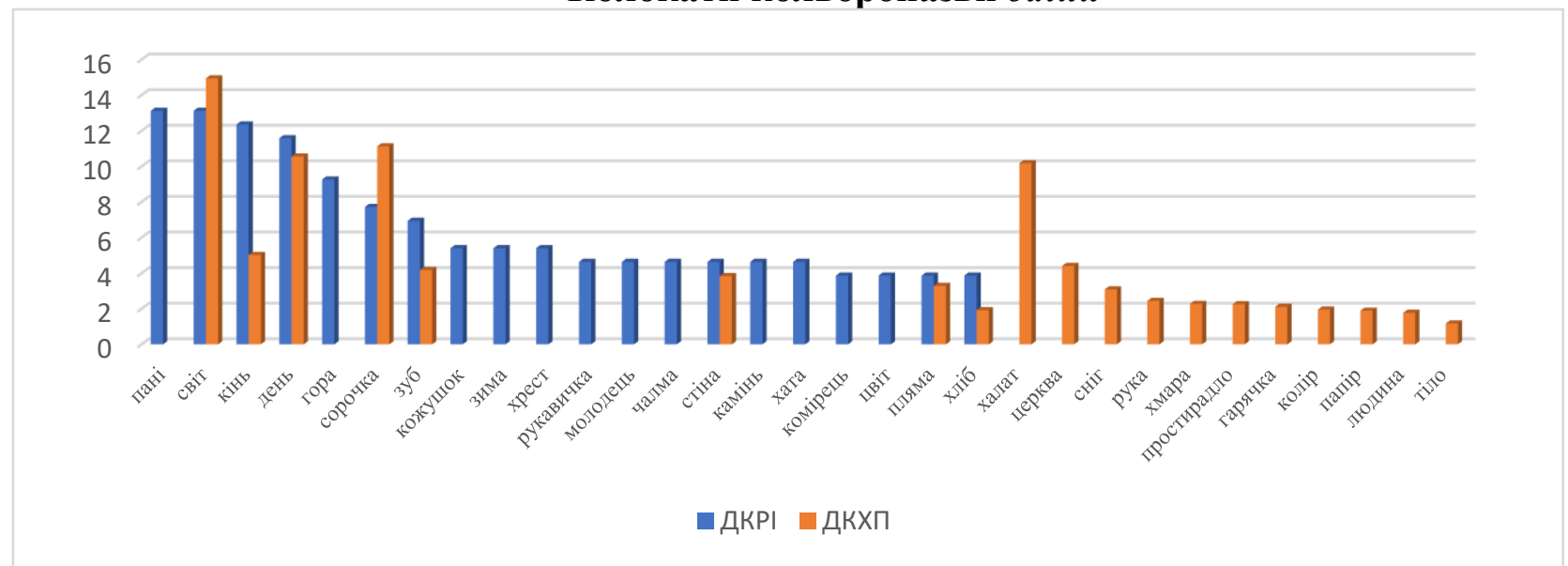

Найчастотнішим колокатами кольороназви білий у ДКРІ є $n a н i^{3}$ 13,12, cвim 13,12, кінь 12,35, день 11,58, гора 9,26, сорочка 7,72, зуб 6,94; у ДКХП-світ 14,94, день 10,55, сорочка 11,12, халат 10,17; у ДКРІ і ДКХП числові показники для колокатів світ, день корелюють. Тим часом у ДКРІ частота колокатів кінь, хліб, зуб значно перевищують показники цих слів у ДКХП, на 60\%, 50\%, 40\% відповідно. У ДКРІ статистичні величини колоката сорочка є на 30\% нижчою, ніж у ДКХП. Належить зауважити, що у ДКРІ простежено такі високочастотні колокати пані, гора, кожушок, зима, хрест, рукавичка, молодець, чалма, камінь, хата, комірець, ивіт, які не ввійшли до високочастотних у ДКХП.

В українській мові кольороназва білий ${ }^{4} \epsilon$ «символом світла, сонця, життя, вічності, святості, божества; місяця; смерті; радості, святковості; сакрального для українців» (ССКУ: 24). У свідомості українців біле пов'язане з божественним, чистим, світом, красою, душевністю (ССКУ: 24). Так, словосполуки білі стіни (білостінний), біла хата вербалізують прототипне уявлення про українське село та $\epsilon$ символами рідної землі, тепла і затишку (ССКУ: 228). Колокації біла сорочка, біла хустина, білий рушник є типовими і водночас са-

\footnotetext{
${ }^{3}$ Біла Пані - це персонаж у романах Р. Іваничука «Вогненні стовпи», «Через перевал».

${ }^{4}$ СУМ 1фіксує такі значення прикметника білий: 1) який має колір крейди, молока, снігу, протилежне чорний; // уживається як постійний епітет до деяких назв; // вимитий, випраний, чистий; // посивілий, сивий, сивочолий; // зблідлий, блідий; // безколірний, безбарвний, прозорий; // у значенні іменника біле; 2) на якому є багато білих плям, вибілених предметів тощо; 3) світлошкірий про расу (СУМ 1: 181).
} 
кральними для української мовної картини світу. Тим часом білий фартух є елементом українського національного жіночого костюма (Жайворонок: 614), біла фата - весільний головний убір нареченої (СУМ 10: 569).

За О. Левченко, атрибутом білий наділено концепти СВІТ, ДЕНЬ (Левченко 2011: 27). Найчастотнішими словосполуками з компонентом білий у Р. Іваничука виступають білий світ, білий день, які фіксують словники (СФУМ: 534; СУМ 10: 569).

У ДКРІ високочастотний колокат-соматизм зуби кольороназви білий простежено в таких висловах: густі білі зуби, світити білими зубами, блиснути/зблиснути білими зубами, оскал біли зубів/оскалені білі зуби, ошкірити/вишкірити білі зуби; а також - груди, ичиі, перса: «Вона розстебнула один тудзик на мережаній кофтині і жолобець поповз униз, розділяючи два білі бохонці персів» (Манускрипт з вулиці Руської); «...вона розстібнула кабатину, з пазухи випорснули білі циці...» (Вогненні стовпи); «...вона розстібнула блузочку, білі перса випорснули з пазухи...» (Хресна проща).

Колокати кольороназви білий, як-от ряст, иввіт, береза (білокора береза) є народно-поетичними епітетами і символізують невинність, чистоту, радість та ін. У ДКРІ частотною $є$ колокація білий кінь: Випав сніг на Михайла - а святий архістратиг приїхав на білому коні (Манускрипт з вулиці Руської); Попереду довгої імператорської валки їхав на білому коні султан Ібрагім (Мальви).

Письменник уживає атрибут білий у символічному значенні. Серед таких уживань можна виокремити загальномовні сталі сполуки 78/60,23 (СУМ 1, 181): білий світ 17/13,12, на білому світі 14/10,81; білий день 13/10,03; серед білого дня 11/8,49, чорним по білому 5/3,86; біла гарячка, білий хліб 4/3,09, біла душа 3/2,32, в білий день, біла магія 2/1,54, біла ворона, біле чудо, біла тиша, по білому світі 1/0,77. Окрім того, у ДКРІ наявні сполуки, які не фіксують словники з огляду на їхню низьку частотність, не натрапляємо на них в ілюстративних контекстах: біла втіха 'цвіт' («...біла втіха сиротливо пролетить над кущем...» (Журавлинний крик)). Однак знайдено кілька вживань цісї словосполуки в сучасних текстах: Хуртовина біла втіха, Біло вбілює хати! (Анатолій Камінчук); Дзвенять-летять з безодні мідяки. Блищзать сльозою на трагічних стріхах. Там зойк... там Смерть... там біла-біла втіха... - ÏI цілунки - чорні нагідки. (Анатолій Сазанський, 1952). Цікаво, що в одній із методичних розробок дітям запропоновано завдання: Як іще можна назвати хуртовину? (Завірюха, заметіль, метелиия, біла втіха, віхола) (За матеріалами журналу “Джміль”, 1999, № 4). Контекстуально «політичну» символіку транслює вислів біла зараза (1/0,77): Знай: ні я, ні тато не за комуну. - Тата облишмо. А тобі скажу: залізла в душу біла зараза - вбий відразу, щзоб не довелося комусь за це братися (Край битого шляху). У низці сучасних текстів натрапляємо на поодинокі вживання словосполуки біла зараза стосовно явищ оцінюваних негативно і які мають реальну колірну ознаку білий: Вночі постійно падає ия біла зараза! У мене криваві мозолі на руках і болі в спині від прибирання снігу! (vk.com > notes20703902); Мало того, щзо ціле літо жуки, тля, кліщі на трояндах, то останній рік щее й на капусті якась нова біла зараза була (forum.kozovod.com > na-sel).

У текстах Р .Іваничука наявне вживання кольороназви білий у порівняльних зворотах, як-от: білий, мов шума під водоспадом 2/1,54; буханець білого, як паска, хліба; дитину, що була біла, як шума на молочі; білий, мов шумка на молоці; ідуть шнурком люди з повними кошиками - білі, мов лебеді; біле, мов з алебастру виліплене, вушко; біла, немов весняна хмарка, дівчинка; білий, мов лебедичя; білий мов полотно; зблиснувши білими, мов перли, зубами; обличчя білим мов папір; білий, мов черемха; білий, немов розмай черемхи. Спостерігаємо вживання загальномовних порівняльних конструкцій білий, мов лебедi; білі, мов перли, зуби; білий мов полотно; білий мов папір, а також їхніх трансформацій. Простежено трансформацію стабілізованих порівнянь білий як піна і білий як молоко (Левченко 2011: 97, 101): у порівняннях білий, мов шума під водоспадом, біла, як шума на молоці замінено компонент піна $\rightarrow$ шума/шумка та розширено компонентний склад (під водоспадом/на молоиі). Розширення компонентного складу наявне також в одиниці біле, мов з алебастру 
виліплене (стабілізованою є одиниця білий як алебастр (Левченко 2011: 86); біла, немов весняна хмарка, дівчинка (стабілізованою є одиниця білий мов хмара (як хмаринка) (Левченко 2011: 99). Заміну компонентного складу простежено у порівняннях білий, як паска (стабілізованою є одиниця білий як хліб (Левченко 2011:90); білий, мов лебедиия (стабілізованою є одиниця білий як лебідь (Левченко 2011: 86). У сполуках білий, мов черемха; білий, немов розмай черемхи конкретизовано образ (стабілізованою є одиниця білий як иявіт (Левченко 2011: 87).

У ДКХП типовими порівняльними конструкціями є: білий, як/мов/немов сніг 0,9, молоко 0,5, крейда 0,3 , сметана, стіна 0,2 , лебідь 0,18 , полотно 0,16 , папір 0,13 , лунь 0,12 , льон 0,1 , смерть 0,1, сонще 0,08, голуб 0,06; тісто, морська піна, вата, вареник, иукор, перший сніг 0,05; збиране молоко, перли, грудка, примара, піна, привид, сіль, свічка, хмара 0,04; блідий як/мов смерть 0,52, крейда 0,28, стіна 0,25 , полотно 0,1, мрець 0,$09 ;$ світлий, як/мов/немов пряжене молоко, ніжний льон, сонце 0,02. За результатами асоціативних експериментів С. Мартінек дійшла висновку, що «психологічно найвагомішою точкою референції для білого в українській мові є сніг» (Мартінек 2002: 346). У ДКХП порівняння білий як/мов/немов сніг є найчастотнішою конструкцією, проте у ДКРІ це порівняння є низькочастотним.

Висновки. Здобуті дані свідчать, що корпус текстів письменника дає змогу комплексно проаналізувати лексикон автора, простежити частотність мовних одиниць та їхню сполучуваність 3 іншими елементами. Власне корпуснобазований підхід та статистичний аналіз текстових масивів ДКРІ дав змогу представити високочастотні та низькочастотні колокати кольороназви білий; тематичні групи колокатів атрибута білий; символічні значення та загальномовні сталі сполуки з кольором білий; порівняльні конструкції з досліджуваним компонентом.

Аналіз кольороназви білий виявив, що найчастотнішими моделями у ДКРІ є прийменникові, серед яких простежено сполуки зі семантикою причини. Із аналізу випливає, що слово білий у текстах Р. Іваничука найчастіше виступає атрибутом одягу (23\%), простору та природніх явищ $(17 \%)$.

Аналіз найчастотніших колокатів кольороназви білий виявив, що у ДКРІ частота колокатів кінь, хліб, зуб удвічі перевищують показники цих слів у ДКХП, проте частота колоката сорочка є на третину нижчою, ніж у ДКХП. У ДКРІ простежено вживання таких високочастотних колокатів кольору білий, як-от: nані, гора, кожушок, зима, хрест, рукавичка, молодець, чалма, камінь, хата, комірець, ивіт, яких не виявлено серед високочастотних у ДКХП.

Прототипні референти білого в ідіолекті Р. Іваничука репрезентують його світобачення як представника певного лінгвокультурного ареалу. Так, прототипами білого в текстах Р. Іваничука є: иума, паска, лебідь/лебедиия, алебастр, хмарка, полотно, перли, папір, иукор, рушник, день, зоря; натомість у ДКХП - сніг, молоко, крейда, сметана, стіна, лебідь, полотно, nапір.

Корпуснобазований та лінгвокогнітивний підходи аналізу кольороназв на основі колокацій представляють лексикон й авторські вподобання та відкривають перспективи для подальшого дослідження текстів Р. Іваничука.

\section{Література}

Бабій, Ірина М. Семантика, структура та стилістичні функції назв кольорів у сучасній українській мові (на матеріалі малої прози В. Стефаника, М. Коцюбинського, М. Хвильового): дис.... канд. філол. наук: 10.02.01 «Українська мова». Київ, 1997.

[Babiy, Iryna M. Semantyka, struktura ta stylistychni funktsiyi nazv kol'oriv u suchasniy ukrayins'kiy movi (na materiali maloyi prozy V. Stefanyka, M. Kotsyubyns'koho, M. Khvyl'ovoho): dys.... kand. filol. nauk: 10.02.01 «Ukrayins'ka mova». Kyyiv, 1997.]

Бобкова, Тетяна В. Теоретико-методологічні підходи до вивчення колокацій. Вісник Київського наи. лінгв. ун-ту. Серія: Філологія. Т. 17. № 2. 2014, 14-22. 
[Bobkova Tetyana V. Teoretyko-metodolohichni pidkhody do vyvchennya kolokatsiy. Visnyk Kyyivs'-koho nats. linhv. un-tu. Seriya: Filolohiya. T. 17. № 2. 2014, 14-22.]

Бойко, Надія I., Коткова Людмила І. Експресивний потенціал ідіолекту Володимира Винниченка: лексичні та фразеологічні складники. Ніжин: НДУ ім. М. Гоголя, 2017.

[Boyko, Nadiya I., Kotkova Lyudmyla I. Ekspresyvnyy potentsial idiolektu Volodymyra Vynnychenka: leksychni ta frazeolohichni skladnyky. Nizhyn: NDU im. M. Hoholya, 2017.]

Бук, Соломія. Сучасні методи дослідження мови письменника у слов'янознавстві. Проблеми слов'янознавства. Вип. 61. 2012: 86-95.

[Buk, Solomiya. Suchasni metody doslidzhennya movy pys'mennyka u slov"yanoznavstvi. Problemy slov'yanoznavstva. Vyp. 61. 2012: 86-95.]

Василевич, Александр П., Кузнецова Светлана Н., Мищенко Сергей С. Цвет и названия цвета в русском языке. Москва: КомКнига, 2005.

[Vasilevich, Aleksandr P., Kuznetsova Svetlana N., Mishchenko Sergey S. Tsvet i nazvaniya tsveta v russkom yazyke. Moskva: KomKniga, 2005.]

Вежбицкая, Анна. Язык. Культура. Познание, М.А. Кронгауз (пер. с англ.; отв. ред.); Е.В. Падучева (вступ. ст.). Москва: Русские словари, 1996.]

[Vezhbitskaya, Anna. Yazyk. Kul'tura. Poznaniye, M.A. Krongauz (per. s angl.; otv. red.); E.V. Paducheva (vstup. st.). Moskva: Russkiye slovari, 1996.]

ГРАК: Генеральний регіонально анотований корпус української мови. http://uacorpus.org/ [Доступ 07.12.2020].

[HRAK: Heneral'nyy rehional'no anotovanyy korpus ukrayins'koyi movy. http://uacorpus.org/]

Губарева, Галина А. Семантика та стилістичні функції кольоративів у поетичній мові Ліни Костенко: автореф. дис. ... канд. філол. наук: 10.02.01 «Українська мова», Харків, 2002.

[Hubareva, Halyna A. Semantyka ta stylistychni funktsiyi kol'oratyviv u poetychniy movi Liny Kostenko: avtoref. dys. ... kand. filol. nauk: 10.02.01 «Ukrayins'ka mova», Kharkiv, 2002.]

Дарчук, Наталія. Комп’ютерне анотування українського тексту: результати і перспективи. Київ: Освіта України, 2013.

[Darchuk, Nataliya. Komp"yuterne anotuvannya ukrayins'koho tekstu: rezul'taty i perspektyvy. Kyyiv: Osvita Ukrayiny, 2013.]

Жайворонок, Віталій В. Знаки української етнокультури: Словник-довідник. Київ, 2006.

[Zhayvoronok, Vitaliy V. Znaky ukrayins'koyi etnokul'tury: Slovnyk-dovidnyk. Kyyiv, 2006.]

Єсипенко, Надія Г. Лексико-семантичні компоненти авторського стилю і мовна картина світу (на матеріалі англомовної прози воєнної та мирної тематик): автореф. дис. ... канд. філол. наук: 10.02.04 «Германські мови». Чернівці, 2007.

[Yesypenko, Nadiya H. Leksyko-semantychni komponenty avtors'koho stylyu i movna kartyna svitu (na materiali anhlomovnoyi prozy voyennoyi ta myrnoyi tematyk): avtoref. dys. ... kand. filol. nauk: 10.02.04 «Hermans'ki movy». Chernivtsi, 2007.]

Захаров, Виктор П. Сочетаемость через призму корпусов. Компьютерная лингвистика и интеллектуальные технологии: по материалам ежегодной Международной конференции «Диалог» (Москва, 27-30 мая 2015 г.). Вып. 14 (21). Т. 1. Москва, 2015: 667-682.

[Zakharov, Viktor P. Sochetayemost' cherez prizmu korpusov. Komp'yuternaya lingvistika $i$ intellektual'nyye tekhnologii: po materialam ezhegodnoy Mezhdunarodnoy konferentsii «Dialog» (Moskva, 27-30 maya 2015 g.). Vyp. 14 (21). T. 1. Moskva, 2015: 667-682.]

Кацнельсон, Соломон Д. Содержание слова, значение и обозначение, В.М. Жирмунского, М.М. Гухман, С.Д. Кацнельсона (под общ. ред.). [изд. 3-е]. Москва: Едиториал УРСС, 2011.

[Katsnel'son, Solomon D. Soderzhaniye slova, znacheniye i oboznacheniye, V.M. Zhirmunskogo, M.M. Gukhman, S.D. Katsnel'sona (pod obshch. red.). [izd. 3-e]. Moskva: Editorial URSS, 2011.]

Левченко, Олена. Українсько-російсько-білорусько-болгарсько-польський словник порівнянь. Львів: Вид-во Національного університету «Львівська політехніка», 2011.

[Levchenko, Olena. Ukrayins'ko-rosiys'ko-bilorus'ko-bolhars'ko-pol's'kyy slovnyk porivnyan'. L’viv: Vyd-vo Natsional'noho universytetu «L'vivs'ka politekhnika», 2011.] 
Левицкий, Виктор В. Квантитативные методы в лингвистике. Винница: Нова Книга, 2007.

[Levitskiy, Viktor V. Kvantitativnyye metody v lingvistike. Vinnitsa: Nova Kniga, 2007. 264 s.]

Мартінек, Світлана В. Концептуалізація білого та чорного кольорів (за результатами асоціативного експерименту). Мовні і конщептуальні картини світу. Bun. 7. 2002:338-347.

[Martinek, Svitlana V. Kontseptualizatsiya biloho ta chornoho kol'oriv (za rezul'tatamy asotsiatyvnoho eksperymentu). Movni i kontseptual'ni kartyny svitu. Vyp. 7. 2002:338-347.]

Мухин, Михаил Ю. Лексическая статистика и идиостиль автора: корпусное идеографическое исследование (на материале произведений М. Булгакова, В. Набокова, А. Платонова и М. Шолохова): автореф. дисс. ... д-ра филол. наук: 10.02.19. Уральский государственный университет им. А.М. Горького. Екатеринбург, 2011.

[Mukhin, Mikhail Yu. Leksicheskaya statistika i idiostil' avtora: korpusnoye ideograficheskoye issledovaniye (na materiale proizvedeniy M. Bulgakova, V. Nabokova, A. Platonova i M. Sholokhova): avtoref. diss. ... d-ra filol. nauk: 10.02.19. Ural'skiy gosudarstvennyy universitet im. A.M. Gor'kogo. Ekaterinburg, 2011.]

Москович, Вольф А. Система цветообозначения в современном английском языке. Bonpocbl языкознания. № 6. 1960: 83-86.

[Moskovich, Vol'f A. Sistema tsvetooboznacheniya v sovremennom angliyskom yazyke. Voprosy yazykoznaniya. № 6. 1960: 83-86.]

Наумов, Владимир В. Лингвистическая идентификация личности. Москва: КомКнига, 2006.

[Naumov, Vladimir V. Lingvisticheskaya identifikatsiya lichnosti. Moskva: KomKniga, 2006.]

Півень, Володимир Ф. Ідіостиль поетичних творів Святослава Гординського: автореф. дис. ... канд. філол. наук: 10.02.01 «Українська мова». Запоріз. нац. ун-т. Запоріжжя, 2007.

[Piven', Volodymyr F. Idiostyl' poetychnykh tvoriv Svyatoslava Hordyns'koho: avtoref. dys. ... kand. filol. nauk: 10.02.01 «Ukrayins'ka mova». Zaporiz. nats. un-t. Zaporizhzhya, 2007.]

Семашко, Тетяна Ф. Особливості семантики та функціонування слів-колоративів в українській фразеології: автореф. дис. ... канд. філол. наук: 10.02.01 «Українська мова». Київ, 2008.

[Semashko, Tetyana F. Osoblyvosti semantyky ta funktsionuvannya sliv-koloratyviv $\mathrm{v}$ ukrayins'kiy frazeolohiyi: avtoref. dys. ... kand. filol. nauk: 10.02.01 «Ukrayins'ka mova». Kyyiv, 2008.]

Ситар, Ганна В. Статистичний аналіз прислів'їв і приказок: показник асоціації mutual information (на матеріалі Українського національного лінгвістичного корпусу). Лінгвістичні студіï, Вип. 35, 2018, 170-177.

[Sytar, Hanna V. Statystychnyy analiz prysliv"yiv i prykazok: pokaznyk asotsiatsiyi mutual information (na materiali Ukrayins'koho natsional'noho linhvistychnoho korpusu). Linhvistychni studiyi, Vyp. 35, 2018, 170-177.]

СУМ-11 - Словник української мови: в 11 т. І.К. Білодід (за ред.). АН УРСР. Ін-т мовознавства; Київ: Наукова думка, 1970-1980.

[SUM-11 - Slovnyk ukrayins'koyi movy: v 11 t. I.K. Bilodid (za red.). AN URSR. In-t movoznavstva; Kyyiv: Naukova dumka, 1970-1980.]

ССКУ - Словник символів культури України. В.П. Коцур, О.І. Потапенко, М.К. Дмитренко (заг. ред.). Київ: Міленіум, 2002.

[SSKU - Slovnyk symvoliv kul'tury Ukrayiny. V.P. Kotsur, O.I. Potapenko, M.K. Dmyt-renko (zah. red.). Kyyiv: Milenium, 2002.]

СФУМ - Словник фразеологізмів української мови: у 2 кн. В.М. Білоноженко та ін. (уклад.). Київ: Наукова думка, 2003.

[SFUM - Slovnyk frazeolohizmiv ukrayins'koyi movy: u 2 kn. V.M. Bilonozhenko ta in. (uklad.). Kyyiv: Naukova dumka, 2003.]

Сніжко, Наталія. Українська ідеографія: історія, сучасний стан та перспективи. Українська мова. № 3. 2016: 28-43.

[Snizhko, Nataliya. Ukrayins'ka ideohrafiya: istoriya, suchasnyy stan ta perspektyvy. Ukrayins 'ka mova. № 3. 2016: 28-43.] 
Супрун, Людмила О. Семантика і прагматика назв кольорів в українському романному тексті середини другої половини XX ст. (на матеріалі творів О. Гончара, П. Загребельного, М. Стельмаха): дис. ... канд. філол. наук: 10.02.01 «Українська мова». Харків, 2009.

[Suprun, Lyudmyla O. Semantyka i prahmatyka nazv kol'oriv v ukrayins 'komu romannomu teksti seredyny druhoyi polovyny KhKh st. (na materiali tvoriv O. Honchara, P. Zahrebel'noho, M. Stel'makha): dys. ... kand. filol. nauk: 10.02.01 «Ukrayins'ka mova». Kharkiv, 2009.]

Тернер, Виктор. Символ и ритуал. Москва: Наука, 1983.

[Terner, Viktor. Simvol i ritual. Moskva: Nauka, 1983.]

Тулдава, Юхан А. Проблемы и методы квантитативно-системного исследования лексики. Таллин: Валгус, 1987.

[Tuldava, Yukhan A. Problemy i metody kvantitativno-sistemnogo issledovaniya leksiki. Tallin: Valgus, 1987.]

Marcinkevičienè, Rūta. Lietuvių kalbos kolokacijos: [monografija]. [In:] Kaunas: Vytauto Didžiojo universiteto leidykla, 2010.

Sinclair, John. Corpus, Concordance, Collocation. Oxford: Oxford University Press, 1991.

Tognini-Bonelli, Elena. Corpus Classroom Currency. [In:] Darbai ir Dienos, № 24, 2000, 205-243.

\section{Використані джерела}

Іваничук Роман. Край битого шляху: роман. Київ: Молодь, 1962.

[Ivanychuk Roman. Kray bytoho shlyakhu: roman. Kyyiv: Molod', 1962.]

Іваничук Роман. Черлене вино: романи. Львів: Каменяр, 1979.

[Ivanychuk Roman. Cherlene vyno: romany. L’viv: Kamenyar, 1979.]

Іваничук Роман. Четвертий вимір: роман. Київ: Радянський письменник, 1984.

[Ivanychuk Roman. Chetvertyy vymir: roman. Kyyiv: Radyans'kyy pys'mennyk, 1984.]

Іваничук Роман. Шрами на скалі: роман. Львів: Каменяр, 1987.

[Ivanychuk Roman. Shramy na skali: roman. L’viv: Kamenyar, 1987.]

Іваничук Роман. Бо війна війною...; Через перевал: романи. Харків: Фоліо, 2008.

[Ivanychuk Roman. Bo viyna viynoyu...; Cherez pereval: romany. Kharkiv: Folio, 2008.]

Іваничук Роман. Вогненні стовпи: тетралогія. Харків: Фоліо, 2011.

[Ivanychuk Roman. Vohnenni stovpy: tetralohiya. Kharkiv: Folio, 2011.]

Іваничук Роман. Євангеліє від Томи: триптих повістей. Харків: Фоліо, 2011.

[Ivanychuk Roman. Yevanheliye vid Tomy: tryptykh povistey. Kharkiv: Folio, 2011.]

Іваничук Роман. Манускрипт з вулиці Руської: іст. роман. Львів: ЛА «Піраміда», 2011.

[Ivanychuk Roman. Manuskrypt z vulytsi Rus'koyi: ist. roman. L’viv: LA «Piramida», 2011.]

Іваничук Роман. Хресна проща: романний триптих. Львів: Піраміда, 2011.

[Ivanychuk Roman. Khresna proshcha: romannyy tryptykh. L'viv: Piramida, 2011.]

Іваничук Роман. Мальви; Орда: романи. Харків: Фоліо, 2012.

[Ivanychuk Roman. Mal'vy; Orda: romany. Kharkiv: Folio, 2012.]

Іваничук Роман. Журавлиний крик: роман. Харків: Фоліо, 2014.

[Ivanychuk Roman. Zhuravlynyy kryk: roman. Kharkiv: Folio, 2014.]

Іваничук Роман. Вода з каменю; Саксаул у пісках: романи. Харків: Фоліо, 2015.

[Ivanychuk Roman. Voda z kamenyu; Saksaul u piskakh: romany. Kharkiv: Folio, 2015.]

Іваничук Роман. Голоси з-над вод Генісарета: колаж; Я ще не писав про Донбас: рефлексії.

Львів: Срібне слово, 2016.

[Ivanychuk Roman. Holosy z-nad vod Henisareta: kolazh; Ya shche ne pysav pro Donbas: refleksiyi. L'viv: Sribne slovo, 2016.] 


\section{COLOUR NOMINATION БІЛИЙ (WHITE) AS AN IDIOLECT MARKER (BASED ON R. IVANYCHUK'S TEXTS) \\ Olena Levchenko \\ Department of Applied Linguistics, Lviv Polytechnic National University \\ Nataliia Lototska Ukraine \\ Department of Foreign Languages and Translation, Lviv State University of Life Safety,}

\section{Abstract}

Background: Colour nominations are important elements for modeling the world by a linguistic personality. Text corpus allows to study the connectivity of lexical units, for regularly generated syntagmatic structures play a significant role in text construction. Meanwhile statistical methods provide reliable quantitative data on the compatibility of lexical units based on corpus texts.

Purpose: The purpose of the analysis is to describe and analyze the colour nomination БІЛИЙ (WHITE) in R. Ivanychuk's text corpus and to detect the specific characteristics of the author's idiolect.

Results: The colour БІЛИЙ (WНІТЕ) forms the core of colours in linguistic studies and is the high-frequent colour nomination in R. Ivanychuk's text corpus. Corpus-based, quantitative and cognitive approaches are used to describe and analyze the author's word combinations with colour nomination БІЛИЙ (WHITE) as a marker of his idiolect.

Discussion: During the research structural-semantic models of colligations and collocations with colour component БІЛИЙ (WHIТЕ) are described; thematic groups of typical collocates for colour БІЛИЙ (WHITЕ) are derived; high-frequency collocates of БІЛИЙ (WHITЕ) are presented, colour prototypes are described, colour symbolics in the author's idiolect is revealed in R. Ivanychuk's text corpus.

The practical significance of obtained list of collocations with colour БІЛИЙ (WHITE) in R. Ivanychuk's text corpus is important for text identification and attribution. Meanwhile, cognitive approach of the text study represents the writer's concept sphere based on colour prototypes to highlight certain aspects typical for the author's idiolect.

Keywords: idiolect, collocation, colligation, colour nomination, text corpus, association measures, statistical analysis, word combination.

Vitae

Olena Levchenko, head of Department of Applied Linguistics, DSc(Philology), Prof., Lviv Polytechnic National University. Areas of research interests include functional linguistics, cognitive linguistics, comparative linguistics, corpus linguistics, lexicographic linguistics, quantitative linguistics and text linguistics.

Nataliia Lototska, lecturer at the Department of Foreign Languages and Translation, Lviv State University of Life Safety. Areas of research interests include cognitive linguistics, corpus linguistics, quantitative linguistics, and text linguistics.

Correspondence: levchenko.olena@gmail.com; nata07lototska@gmail.com

Надійшла до редакції 23 березня 2021 року Рекомендована до друку 6 квітня 2021 року 